\title{
Elements of Technology Enabled/Enhanced Active Learning (TEAL) to Enhance Quality and Employability of Bachelor's Students
}

\author{
Nur Farha Bte Hassan ${ }^{1, *}$, Saifullizam Bin Puteh ${ }^{1}$, and Amanina Binti Muhamad Sanusi ${ }^{1}$ \\ ${ }^{1}$ Faculty of Technical and Vocational Education, Universiti Tun Hussein Onn Malaysia, 86400 Batu Pahat, Johor, Malaysia.
}

\begin{abstract}
The application of technology innovation is rapidly increasing in industries and educational institutions. This phenomenon has led to the emergence of Technology Enabled/Enhanced Active Learning (TEAL) which emphasizes the use of various techniques and technologies. TEAL is a new learning format that combines educational content from a lecturer, simulation, and student's experiences using technological tools to provide a rich collaborative learning experience for students. This approach is used to provide academic professional development that brings innovation to the learning content, practically by using pedagogy, technology and classroom design. TEAL ensures the enhanced development of student's knowledge and skills in order to produce quality skilful workers with adequate employability skills. Technology is an effective tool used to facilitate the teaching and learning process, which can, in turn, create an active environment for students to build their knowledge, skill and experience. This paper determines the elements of TEAL based on interview sessions with expert academicians and from a systematic literature review. The selection of TEAL elements for this study was carried out using thematic analysis approach. Findings show that these TEAL elements would help institutions to promote students in involving themselves in active learning in order to enhance the quality of graduates in improving their technical knowledge, thereby enhancing their employability skills.
\end{abstract}

Keywords: Technology Enabled/Enhanced Active Learning (TEAL), Technologies, Pedagogies and Content Knowledge (TPACK)

\section{Introduction}

Nowadays, engineering and technology industries have a high demand for bachelor degree graduates from Technical and Vocational Education and Training (TVET) programs. TVET programs prepare individuals for work in technical areas and provide these individuals with skills, knowledge, experience and marketability in applied innovation technology [1]. The unemployment rate of bachelor graduates is high, and this has been closely linked to the problem of inadequate knowledge, skills and attitudes of graduates in applied technology and technical work for labour market requirements in the industrial sector [2,3]. Figure 1.1 shows that the highest unemployment rates in Malaysia were bachelor degree graduates with a $27.9 \%$ unemployment rate compared respective groups as reported in the data source obtained from the Ministry of Higher Education and Bank Negara Malaysia estimates [4].

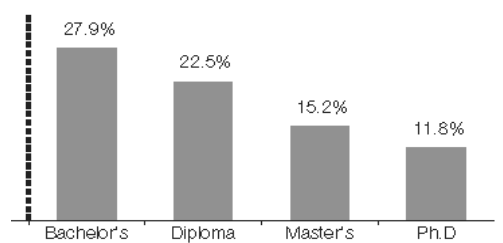

Fig. 1.1: Unemployment Rates of Graduates by Qualification (Ibrahim \& Mahyuddin, 2017)
This indicates that TVET institution needs to prepare bachelor degree graduates with communication skills, technology skills, employability skills and marketability skills to improve their performance gradually [5]. More specifically in providing opportunities for students to apply technology tools practically while engaging in an active learning environment [6].

Thus, Technology Enabled/Enhanced Active Learning (TEAL) can be applied in the learning process. It will help students to meet the demand of industry needs. That is graduates who are skilful, talented, knowledgeable, hand's on practices, with a right attitude and willingness to share ideas to improve the quality of jobs in industrial organizations [6,7]. Therefore, an innovative learning format in applying digital technology, Information and Communications Technology (ICT) equipment, electronic media, application tools, multimedia tools and machine tools are needed. This innovative learning format for these crucially selected elements is required in order to improve the quality of learning in simulations, hands-on and short lectures from instructors [8].

In this paper, to produce technology active learning in education, there is need to refer to the learning pyramid by. $[9,10]$ to help students learn in productive ways so that student can master knowledge related to employability skills. Similarly, in order to produce active

\footnotetext{
${ }^{*}$ Corresponding author: hb140185@siswa.uthm.edu.my
} 
learning model, students should be involved in the learning activities.

Students will be given a chance to practice with group discussions, collaborative activities; practical hands-on and active learning during the class session [7]. From figure 1.2 shows the learning pyramid. Effective learning was divided into two parts; namely passive learning such as lectures, reading, audiovisuals and demonstrations; and active learning such as group discussion, practical and collaborative activities [9, 11].

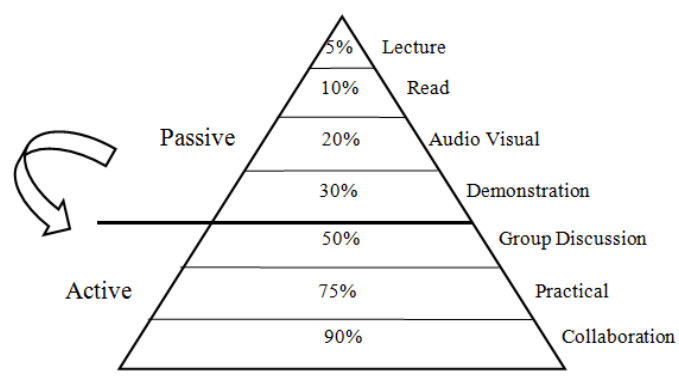

Figure1.2: Learning Pyramid (Lalley, James, Miller \& Robert,2007)

The learning pyramid shows that $50 \%$ of students need to participate in group discussion, $75 \%$ for practical hands-on and $90 \%$ for collaborative activities to create active learning environment [9]. In addition, to create more efficient learning, technology will be applied to active learning activities to ensure that students will obtain a better understanding of the learned concept during class sessions [11]. This will help students to become high-quality workers when they employed in various job roles in industries.

Therefore, the theory of Practice Technologies, Pedagogies and Content Knowledge (TPACK) needs to be used as a platform to build active learning environment [7, 12]. This study utilized the TPACK theory to establish the TEAL concept that requires a combination of active pedagogical learning with technology-rich classrooms in producing an effective learning environment. The application of technology is used to provide activities which constitute the implementation of active learning strategy, as it is more focused on learning outcomes and not on technology tools only and involves students in the learning process [13]. It can help instructors to create effective learning by increasing their learning content and pedagogical knowledge in developing a global mindset to become flexible workers in industries after graduation $[6,12]$.

According to the study [14], TPACK can help institutions to increase knowledge about applied technology in curriculum activities; it will prepare students in practical work, knowledge, and skills in the use of technological equipment and machine tools during classroom sessions. To create an active learning environment, there is a need to start from the basic knowledge of technologies, pedagogies and content to incorporate effective learning [12, 14].

Active learning is fundamental to the educational system, which is in line with global technology needs in learning activities needed to produce skilful graduates who will become manpower for industries, who are knowledgeable, productive, competent in work, excellent talented, have high potentials, are tech-savvy and innovation-minded in applied machine tools especially in technical areas that meet industry demands and institution needs $[5,15,16]$.

Moreover, TEAL needs to be applied in teaching and learning to enhance the quality of graduates by using a variety of methods. That is to assist students to be more interested in the learning process, especially in some elements of online learning, blended learning, collaborative learning, practical learning and interactive learning $[17,18,19]$.

This paper determines the elements of TEAL in enhancing quality and the employability of TVET graduates based on the TPACK theory for preparing graduates to be more active and excellent in applied technology in their studies. The paper is organized under the following headings: Section 2 methodology of the study, section 3 is about the elements of TEAL; Section 4 discusses the outcomes of the study, summaries and conclusion of this paper.

\section{Methodology}

The purpose of this study was to determine the elements of TEAL in solving the problems of unemployed graduates based on the theory of practice (TPACK). This study used thematic analysis approach to identify the element of TEAL. Thematic analysis was performed on data obtained from interview sessions with expert academicians and review of the literature. This paper is necessitated as a response to the need in helping graduate become better-prepared workers after graduation from studies.

\section{Elements of Technology Enabled/Enhanced Active Learning}

The selection of crucial elements of TEAL is based on a summary of interview data and documents from previous research. From the literature and from the perspectives of expert academicians, elements of online learning, blended learning, collaborative learning, practical learning and interactive learning is an approach that is often discussed as being related to learning technology to improve quality and employability of TVET students. TEAL is a technology innovation learning that provides opportunities for TVET students to participate in active lessons and to be involved in quality environment studies as stated in the Malaysia Education Blueprint (Higher Education) 2015-2025 [20,21,22].

This is to prepare students with a variety of approach to learning such as online learning, blended learning, collaborative learning, laboratory learning and interactive learning to build their knowledge and skills related to employability [23]. According to experts, these five elements should be applied in higher education learning and should be embraced by all graduates who want to find a job in industries because they will encounter these elements as a prerequisite to measuring the abilities and skills of graduates while working. 
Based on the feedback from experts, it is more about the graduates needing to prepare themselves with the various skills and knowledge expected by prospective employers. The education system and skills according to [24] have also been highlighted as efforts needed to develop more effective learning in terms of combining aspects of online learning, blended learning, collaborative learning, laboratory learning and interactive learning to enhance quality and producing world-class employable graduates that can achieve goals. Summary of these key elements of TEAL is shown in the following table. Table 3.1 shows key elements of technology-enabled active learning

Table 3.1: Key Element of Technology Enabled Active Learning

\begin{tabular}{|c|c|l|}
\hline \multicolumn{2}{|c|}{ Key Element of Technology Enabled Active Learning } \\
\hline No & \multicolumn{1}{|c|}{ Elements } & \multicolumn{1}{c|}{ Descriptions } \\
\hline 1. & Online learning & $\begin{array}{l}\text { Students can build social and } \\
\text { interpersonal skills to find } \\
\text { information, learn through the } \\
\text { internet and share information } \\
\text { in online conferences. }\end{array}$ \\
\hline 2. & Blended learning & $\begin{array}{l}\text { Students are able to build } \\
\text { organizational and } \\
\text { management skills in face-to- } \\
\text { face learning by using online } \\
\text { technology. }\end{array}$ \\
\hline 3. & $\begin{array}{l}\text { Collaborative } \\
\text { learning }\end{array}$ & $\begin{array}{l}\text { Students are able to build } \\
\text { communication skills by } \\
\text { sharing opinions and working } \\
\text { together in teams to build } \\
\text { motivation and control their } \\
\text { emotions. }\end{array}$ \\
\hline 4. & Laboratory learning & $\begin{array}{l}\text { Students can build technical } \\
\text { skills in applied technology } \\
\text { equipment/machinery to } \\
\text { create a hands-on practice. }\end{array}$ \\
\hline 5. & Interactive learning & $\begin{array}{l}\text { Students are able to build } \\
\text { cognitive, creative and critical } \\
\text { thinking skills in using } \\
\text { multimedia software to } \\
\text { produce a project or product. }\end{array}$ \\
\hline
\end{tabular}

\subsection{Elements of online learning}

Based on interview session and previous journal findings, researchers list the elements of online learning that support the TEAL approach. All these elements are based on the practice theory (TPACK), in producing quality graduates. It was suggested that technology should be used in class lectures. Technology facilitated learning such as using the internet to build knowledge and skills for finding/sharing information in learning. According to the expert's opinion, all these elements need to be applied in a learning session to help students participate in active learning environment using technology tools for improving their knowledge. Research literature [25,26,27], also discusses the effectiveness of applying computer technology in active learning environments and this is dependent on how the tools were used. For example, how accessible are information via the internet or Wi-Fi to facilitate active learning environment, how can a telecommunication media user facilitate online learning sessions with experts in improving student's technical knowledge, how can web application be used to share ideas and how can Internet of thing (IoT) be used to find information to support learning activities?

Additionally, pedagogical knowledge can also be used to help students adapt virtual and web learning to build social interactions. Interpersonal skills can be developed through the use of the internet to find and share information in online conferences [28, 29]. Thus, students are able to build content knowledge by engaging in extensive exploration activities and searching support learning materials in support of creating critical, creative and innovative thinking to solve problems through e-learning and educational web resources. This provides flexibility in the way and manner by which information is accessed at any time and anywhere [30,31,32]. Summary of the elements of online learning are shown in Table 3.2 .

Table 3.2: Elements of Online Learning

\begin{tabular}{|c|c|c|}
\hline \multicolumn{3}{|c|}{ Elements of Online Learning } \\
\hline No & Elements & Description \\
\hline 1. & $\begin{array}{l}\text { Computer } \\
\text { Technology }\end{array}$ & $\begin{array}{l}\text { Students can learn how to handle } \\
\text { the physical hardware of } \\
\text { computer technology to assist in } \\
\text { the learning process }\end{array}$ \\
\hline 2. & Internet and Wi-Fi & $\begin{array}{l}\text { Students can learn in an } \\
\text { environment of learning by } \\
\text { using the internet, intranet and } \\
\text { satellite Wi-Fi in accessing } \\
\text { information }\end{array}$ \\
\hline 3. & $\begin{array}{l}\text { Telecommunication } \\
\text { Media /Mobile } \\
\text { /IPad }\end{array}$ & $\begin{array}{l}\text { Students can more readily use } \\
\text { ICT equipment and tool in } \\
\text { building knowledge of } \\
\text { meaningful learning }\end{array}$ \\
\hline 4. & $\begin{array}{l}\text { Web Application } \\
\text { (Web 2.0) }\end{array}$ & $\begin{array}{l}\text { Students can share ideas and } \\
\text { collaborate in innovative ways } \\
\text { with expert and instructor in } \\
\text { social networks. }\end{array}$ \\
\hline 5. & $\begin{array}{l}\text { IoT (Internet of } \\
\text { Things) }\end{array}$ & $\begin{array}{l}\text { Students can find necessary } \\
\text { support materials from the } \\
\text { internet prior to classes to be } \\
\text { better prepared before attending } \\
\text { such classes or virtual learning }\end{array}$ \\
\hline 6. & $\begin{array}{l}\text { Web and Virtual } \\
\text { Learning }\end{array}$ & $\begin{array}{l}\text { Students can easily get reference } \\
\text { from e-learning, e-training and } \\
\text { web learning }\end{array}$ \\
\hline 7. & Social Interaction & $\begin{array}{l}\text { Students can interact with } \\
\text { colleagues and experts to obtain } \\
\text { or share information }\end{array}$ \\
\hline 8. & $\begin{array}{l}\text { Experience } \\
\text { Learning }\end{array}$ & $\begin{array}{l}\text { Students use technology through } \\
\text { online learning, such as } \\
\text { simulations, quizzes, tests and } \\
\text { debate discussions to build } \\
\text { personal experience }\end{array}$ \\
\hline 9. & $\begin{array}{l}\text { Critical, creative } \\
\text { and innovative in } \\
\text { Problems Solving }\end{array}$ & $\begin{array}{l}\text { Students are able to improve the } \\
\text { thinking of the mind to be more } \\
\text { positive and vast in building } \\
\text { knowledge }\end{array}$ \\
\hline 10. & $\begin{array}{l}\text { Flexibility in } \\
\text { Access Information }\end{array}$ & $\begin{array}{l}\text { Students can search information } \\
\text { online at any time and anywhere }\end{array}$ \\
\hline
\end{tabular}




\subsection{Elements of Blended Learning}

The elements of blended learning are summarised based on the interviews from experts and previous research that had been discussed about the use of a combination of lectures and online learning approach to ensure that the process of teaching and learning is more interesting by using telecommunication media and computer technology applications in class. Feedback from the experts reveals that this can help to build organizational and management skills of students primarily on developing the experience to conduct their own learning with technology. Blended learning is an essential element for enhancing student's competence in the use of digital and electronic technology in class through online conferences with experts to enhance the technical knowledge of students, that technologies application is parallel with $[33,34,35,36]$ research.

Other than that, pedagogical knowledge in blended learning enables students to be more confident in social interaction either with friends or teachers to helps minimize ineffective lecture in the learning process that is supported by virtual learning and to create an active environment using technology applications [37,38]. In fact, content knowledge enables students to be able to gain experience in practical work and presentation skills in flexible conditions and explore the content that had been delivered to the audience [39]. It will help students to develop cognitive thinking and social innovation for preparing them with an occupation in technology equipment, software application and machine tools [40]. Summary of the elements of blended learning are shown in Table 3.3.

Table 3.3: Elements of Blended Learning

\begin{tabular}{|l|l|l|}
\hline \multicolumn{3}{|c|}{ Elements of Blended Learning } \\
\hline No & \multicolumn{1}{|c|}{ Element } & \multicolumn{1}{c|}{ Description } \\
\hline 1. & Online Conference & $\begin{array}{l}\text { Students can conduct online } \\
\text { discussions to ask opinions } \\
\text { from experts and partners in } \\
\text { order to learn easily }\end{array}$ \\
\hline 2. & $\begin{array}{l}\text { Telecommunication } \\
\text { Media and } \\
\text { computer }\end{array}$ & $\begin{array}{l}\text { Students know how to apply the } \\
\text { ICT tools in build technology } \\
\text { knowledge }\end{array}$ \\
\hline 3. & $\begin{array}{l}\text { Digital and } \\
\text { Electronic } \\
\text { Technology / } \\
\text { Clicker Personal } \\
\text { Response System }\end{array}$ & $\begin{array}{l}\text { Students will be able to learn } \\
\text { quickly through digital } \\
\text { equipment using technology } \\
\text { systems for sharing answers by } \\
\text { using clicker }\end{array}$ \\
\hline 4. & $\begin{array}{l}\text { Social Interaction } \\
\text { Students can connect between } \\
\text { friend and teacher in class to } \\
\text { ask questions and share } \\
\text { information }\end{array}$ \\
\hline 5. & Mini-Lecture & $\begin{array}{l}\text { Students listen to a short } \\
\text { description from instructor in } \\
\text { order to know what needs to be } \\
\text { done in the learning process }\end{array}$ \\
\hline 6. & Virtual Learning & $\begin{array}{l}\text { Students can review the } \\
\text { teaching and learning notes via } \\
\text { online platforms. }\end{array}$ \\
\hline 7. & $\begin{array}{l}\text { Flexibility in the } \\
\text { presentation and } \\
\text { exploration of }\end{array}$ & $\begin{array}{l}\text { Students will be able to explore } \\
\text { the contents independently to } \\
\text { aid their learning and share this }\end{array}$ \\
\hline
\end{tabular}

\begin{tabular}{|c|c|c|}
\hline & learning & knowledge during class lessons \\
\hline 8. & $\begin{array}{l}\text { Cognitive and } \\
\text { Social Innovation }\end{array}$ & $\begin{array}{l}\text { Students can train to be more } \\
\text { open-minded in innovation } \\
\text { thinking for developing } \\
\text { projects, products and work }\end{array}$ \\
\hline
\end{tabular}

\subsection{Elements of Collaborative Learning}

Based on interviews conducted and findings in previous journals, the elements of collaborative learning to identify technology knowledge, pedagogical knowledge and content knowledge of students in enhancing quality and employability skills in the future when they work in industries. According to the data collected and analysed, from the interview sessions, all experts highlighted that collaborative learning is critical to be applied in the class, especially in terms of technologies such as using desktop workspace to produce group projects, using web-based software in designing product, developing projects through internet networks and using digital tools to search information needed like those used in researching $[41,42,43]$.

Moreover, group learning can be used to teach students to become confident in social interaction and communication with other people, to create a discussion group, a forum for sharing information, views and knowledge to build teamwork spirit to control emotions and self-motivation when receiving instructions from tutors and peers $[44,45,46]$. In order to create content knowledge, students must be given the chance to build accountability of individual and group to identify their own responsibilities in decision making and taking actions to solve problems, and also to improve critical thinking of students in class discussions [47, 48, 49]. These will help students to create effective learning and become active members of the class while enjoying their lessons at the same time. Summary of elements of collaborative learning are shown in Table 3.4.

Table 3.4: Elements of Collaborative Learning

\begin{tabular}{|l|l|l|}
\hline \multicolumn{3}{|c|}{ Elements of Collaborative Learning } \\
\hline No & \multicolumn{1}{|c|}{ Element } & \multicolumn{1}{c|}{ Description } \\
\hline 1. & $\begin{array}{l}\text { Desktop technology } \\
\text { workspace }\end{array}$ & $\begin{array}{l}\text { Students will be able to learn in } \\
\text { workspaces, and this should be } \\
\text { available for each group }\end{array}$ \\
\hline 2. & $\begin{array}{l}\text { Web-based } \\
\text { software }\end{array}$ & $\begin{array}{l}\text { Students know how to use a } \\
\text { variety of software to share } \\
\text { information through web-based } \\
\text { systems such as Dropbox, } \\
\text { emails, Edmodo and so on. }\end{array}$ \\
\hline 3. & $\begin{array}{l}\text { Internet Network } \\
\text { and Digital Tools }\end{array}$ & $\begin{array}{l}\text { Students can refer to the internet } \\
\text { to get information and operate } \\
\text { digital equipment in group work }\end{array}$ \\
\hline 4. & $\begin{array}{l}\text { Social Interaction } \\
\text { and communication }\end{array}$ & $\begin{array}{l}\text { Students are able to interact with } \\
\text { group members with tolerance } \\
\text { and prudence. }\end{array}$ \\
\hline 5. & $\begin{array}{l}\text { Discussion Group } \\
\text { Forum }\end{array}$ & $\begin{array}{l}\text { Students are more open to } \\
\text { working as a group to share } \\
\text { ideas and opinions. }\end{array}$ \\
\hline 6. & $\begin{array}{l}\text { Instructions Tutor } \\
\text { and Friend }\end{array}$ & $\begin{array}{l}\text { Students will be able to receive } \\
\text { instructions and adhere to the } \\
\text { leader of a group discussion }\end{array}$ \\
\hline 7. & Accountability of & Students are aware of the \\
\hline
\end{tabular}




\begin{tabular}{|c|l|l|}
\hline & $\begin{array}{l}\text { Individual and } \\
\text { Group }\end{array}$ & $\begin{array}{l}\text { responsibilities that should be } \\
\text { shouldered by each individual in } \\
\text { the group }\end{array}$ \\
\hline 8. & $\begin{array}{l}\text { Decision Making } \\
\text { and Action }\end{array}$ & $\begin{array}{l}\text { Students are able to make } \\
\text { decisions in learning with group } \\
\text { discussions }\end{array}$ \\
\hline 9. & $\begin{array}{l}\text { Critical Thinking } \\
\text { and Problem } \\
\text { Solving }\end{array}$ & $\begin{array}{l}\text { Students will be able to think } \\
\text { outside the box and share ideas } \\
\text { with fellow members of the } \\
\text { group }\end{array}$ \\
\hline
\end{tabular}

\subsection{Elements of Practical Learning}

The summary of discussion with expert and literature form some previous studies, reveal that elements of practical learning are related to the use of scientific tools and machinery in the laboratory with ICT and computer equipment to provide opportunity for students to master a variety of skills through web-based software applications in order to build their technological knowledge, as reported in previous studies [50,51,52]. Based on the feedback from the experts, this practical learning is very important as it enables students to have the opportunity to learn from practical projects, as well as learning from products and solutions based on procedural learning to build their own experiences in a conducive learning environment while engaging in group work activities and improving pedagogical knowledge of graduates.

This learning increases the content knowledge of students to build hands-on and experimental skills in handling and controlling devices during practical session in the laboratory $[53,54]$. Through actual experiment, it enables students to perform testing by using hand tools and at the same time building technical experience for students with scientific skills in analysing data with a variety of research's techniques that can be applied in the industries $[55,56]$. The summaries of elements of practical learning are shown in Table 3.5.

Table 3.5: Elements of Practical Learning

\begin{tabular}{|l|l|l|}
\hline \multicolumn{3}{|c|}{ Elements of Practical Learning } \\
\hline No & \multicolumn{1}{|c|}{ Element } & \multicolumn{1}{c|}{ Description } \\
\hline 1. & $\begin{array}{l}\text { Use of Scientific } \\
\text { Tools and } \\
\text { Machinery }\end{array}$ & $\begin{array}{l}\text { Students are able to use } \\
\text { scientific equipment to build } \\
\text { work skills. }\end{array}$ \\
\hline 2. & $\begin{array}{l}\text { ICT Equipment and } \\
\text { Computer } \\
\text { Equipment }\end{array}$ & $\begin{array}{l}\text { Students know how to apply } \\
\text { technology equipment and } \\
\text { computers in doing practical } \\
\text { work }\end{array}$ \\
\hline 3. & $\begin{array}{l}\text { Web-Based } \\
\text { Software }\end{array}$ & $\begin{array}{l}\text { Student can use software in } \\
\text { work simulation }\end{array}$ \\
\hline 4. & $\begin{array}{l}\text { Practical Projects, } \\
\text { Products and } \\
\text { Solutions Based on } \\
\text { Procedure Learning }\end{array}$ & $\begin{array}{l}\text { Students will be able to exert } \\
\text { more effort in trying to } \\
\text { produce products or perform } \\
\text { better in practical work }\end{array}$ \\
\hline 5. & $\begin{array}{l}\text { Conducive } \\
\text { /Experience } \\
\text { Learning }\end{array}$ & $\begin{array}{l}\text { Students can build work skills } \\
\text { when using laboratory } \\
\text { equipment correctly. }\end{array}$ \\
\hline 6. & $\begin{array}{l}\text { Group Work } \\
\text { Activities }\end{array}$ & $\begin{array}{l}\text { Students are able to work in } \\
\text { teams to perform practical } \\
\text { work. }\end{array}$ \\
\hline 7. & $\begin{array}{l}\text { Hands-On } \\
\text { Experimental / }\end{array}$ & $\begin{array}{l}\text { Students are able to enhance } \\
\text { expertise in building work }\end{array}$ \\
\hline
\end{tabular}

\begin{tabular}{|l|l|l|}
\hline 8. & Controlling Devices & skills \\
\hline 9. & $\begin{array}{l}\text { Sctual Experiment } \\
\text { Technical analysis }\end{array}$ & $\begin{array}{l}\text { Students have the opportunity } \\
\text { to perform testing in the } \\
\text { laboratory with the use of } \\
\text { hand tools }\end{array}$ \\
\hline $\begin{array}{l}\text { Students will be skilled in } \\
\text { analysing data with a variety } \\
\text { of research techniques }\end{array}$ \\
\hline
\end{tabular}

\subsection{Elements of Interactive Learning}

Based on the interview conducted with expert academicians and findings from previous studies, the researcher identifies the elements of interactive learning to include knowledge of students in applied technology in the learning process, learning through technology media such as multimedia tools via computer networks and software programming to improve technical skills and the use of digital equipment to produce products [57, 58]. According to the experts, this interactive learning will help students in developing pedagogical knowledge. For instance, in demonstrating their work, animations and graphic designs with audio sound systems can be used to illustrate, while video can be used to display simulation and visualization in game applications can help students to be more interested in the learning process.

Students must be more creative and have high imagination in illustrating so that they can understand what is being learned by visualizing them in their mind $[59,60]$. This learning area is based on the level of student's thinking on how they can become with high productivity in their work, with a high level of cognitive thinking for increasing their learning environment. Thus, making it more flexibility in creating a high performance to produce graduates who are adequate in content knowledge $[61,62]$. Summary of elements of interactive learning are shown in Table 3.6.

Table 3.6: Elements of Interactive Learning

\begin{tabular}{|l|l|l|}
\hline \multicolumn{3}{|c|}{ Element of Interactive Learning } \\
\hline No & \multicolumn{1}{|c|}{ Element } & \multicolumn{1}{c|}{ Description } \\
\hline 1. & $\begin{array}{l}\text { Use of Scientific } \\
\text { Toools and } \\
\text { Machinery }\end{array}$ & $\begin{array}{l}\text { Students are able to use } \\
\text { scientific equipment to build } \\
\text { work skills. }\end{array}$ \\
\hline 2. & $\begin{array}{l}\text { ICT Equipment and } \\
\text { Computer } \\
\text { Equipment }\end{array}$ & $\begin{array}{l}\text { Students know about applying } \\
\text { technology equipment and } \\
\text { computers in doing practical } \\
\text { work }\end{array}$ \\
\hline 3. & $\begin{array}{l}\text { Web-Based } \\
\text { Software }\end{array}$ & $\begin{array}{l}\text { Student be able to use software } \\
\text { for help work simulation }\end{array}$ \\
\hline 4. & $\begin{array}{l}\text { Practical Projects, } \\
\text { Products and } \\
\text { Solutions Based on } \\
\text { Procedural } \\
\text { Learning }\end{array}$ & $\begin{array}{l}\text { Students will give more effort } \\
\text { in trying to produce products or } \\
\text { perform better in practical } \\
\text { work }\end{array}$ \\
\hline 5. & $\begin{array}{l}\text { Conducive } \\
\text { /Experience } \\
\text { Learning }\end{array}$ & $\begin{array}{l}\text { Students can build work skills } \\
\text { when using laboratory } \\
\text { equipment properly }\end{array}$ \\
\hline 6. & $\begin{array}{l}\text { Group Work } \\
\text { Activities }\end{array}$ & $\begin{array}{l}\text { Students are able to work in } \\
\text { teams to perform practical } \\
\text { work }\end{array}$ \\
\hline 7. & Hands-On & Students are able to enhance \\
\hline
\end{tabular}




\begin{tabular}{|c|l|l|}
\hline & $\begin{array}{l}\text { Experimental / } \\
\text { Controlling } \\
\text { Devices }\end{array}$ & $\begin{array}{l}\text { expertise in building work } \\
\text { skills }\end{array}$ \\
\hline 8. & Actual Experiment & $\begin{array}{l}\text { Students have the opportunity } \\
\text { to perform testing in the } \\
\text { laboratory with the use of hand } \\
\text { tools }\end{array}$ \\
\hline 9. & $\begin{array}{l}\text { Scientific Skills } \\
\text { And Analysis } \\
\text { Technical }\end{array}$ & $\begin{array}{l}\text { Students will be skilled in } \\
\text { analysing data using a variety } \\
\text { of research techniques. }\end{array}$ \\
\hline
\end{tabular}

\section{Discussion and Conclusion}

In this study, expert shared their opinions regarding the effectiveness of student's knowledge and skills in order to become skilful workers. This five elements of TEAL approaches needed in TVET institutions, especially for enhancing quality and employability skills of bachelor degree graduates were established from the study. These elements are essential to be applied in classroom settings to ensure that students are able to participate in an active environment to build experience in learning. The combination of all these elements will help graduates to improve their knowledge, skills and experience in technical work by using technology innovation tools.

The five elements of TEAL have their own benefit; online learning help students to find information for their studies; blended learning gives student the opportunity to become flexible in their work and to improve their communication skills; collaborative learning helps to build teamwork spirit in students to enable them to share their ideas and opinions; practical learning helps to ensure that students will be able to handle tools to enhance their hands-on skill; interactive learning helps to ensure that students are able to run multimedia or programming of software to create cognitive thinking.

Each student needs to activate their knowledge as a worker-in-training with various skills for helping them find jobs after graduation. Graduates must be prepared for all the challenges and industrial demand of skilled workers in technologies knowledge that is related to employability skills. This is in line with the theory of practice (TPACK) of pyramid learning for developing an active learning environment. The TEAL approach will guide students in achieving the goals of their studies and help them build knowledge and skills to gain experience.

In conclusion, this study aimed at identifying the elements of TEAL approach, to guide students and lecturers in the learning process in order to create active environments by using technology applications, machinery equipment, digital device, and ICT tools in the class. There are various methods that can be applied to teaching and learning that will attract student's interest to enjoy their studies more. At the same time, lectures will become facilitators to guide students to understand their lesson by applying technology in class either through online or face-to-face method. Lastly, students will become active persons by preparing themselves for industry requirement in job placement. For the next stage, all these elements will be validated by experts and a final checklist will be developed to specify the elements of TEA. Thereafter, it will be analyzed using Fleiss' Kappa agreements.

The author would like to thank to Research Management Centre (RMC), Universiti Tun Hussein Onn Malaysia for supporting this research.

\section{References}

[1] Pang Chau Leong. Key reforms in revitalizing technical and vocational education and training (TVET) in Malaysia. Regional Conference HRD through TVET as a Development Strategy in Asia Colombo, Sri Lanka (2011).

[2] Husain, M. Y. \& Rasul, M. S. \& Mustapha, R. \& Malik, S. A. \& Abd Rauf, R. A. (2013). Tahap kemahiran employability pelajar kejuruteraan dari perspektif majikan. Jurnal Teknologi. 62(1). 31-39.

[3] Yusof, N., Jamaluddin, Z., \& Lazim, N. M. (2013). Persepsi Pelajar Prasiswazah Terhadap Kebolehpasaran Graduan dan Persaingan dalam Pasaran Pekerjaan (The Perception of Undergraduates' Student Towards the Marketability of Graduate and Competition in the Job Market). International Journal of Environment, Society and Space, 1(1). 43-61. Jurnal Personalia Pelajar, 16, 77-92.

[4] Ibrahim, D. H. M., \& Mahyuddin, M. Z. (2017). Youth Unemployment in Malaysia: Developments and Policy Considerations.

[5] Zulkhairi,W., Ismail, R., \& Amirmudin. Critic and different of philosophy in technical and vocational education (TVE). Journal of Edupres, 2(1), 287-300(2011).

[6] Manitoba Education. Technical vocational education overview. The Government of Manitoba, represented by the Minister of Education. ISBN: 978-0-7711-5391-4 (2013).

[7] Hassan, N. F., Puteh, S., \& Buhari, R. Student understanding through the application of technology enabled Active Learning in practical training. Procedia-Social and Behavioral Sciences, 204, 318-325 (2015).

[8] Belcher, J. Technology enabled active learning, Retrieved on May 5, 2007 (2005).

[9] Lalley, James P., Miller \& Robert H., The Learning Pyramid: Does It Point Teachers in the Right Direction?. Education Journal. ISSN-0013-1172, 128 (1), 64-79 (2007).

[10] Baer, J. Lectures may be more effective than you think: The learning pyramid unmasked. The International Journal of Creativity \& Problem Solving, 20(2), 7-21(2010).

[11] Dam, N.V. 25 Best practices in learning \& talent development. Second Edition USA: Lulu Publishers. 136 (2008).

[12] Koehler, M., \& Mishra, P). What is technological pedagogical content knowledge?. Contemporary Issues in Technology and Teacher Education, 9(1), 60-70 (2009).

[13] Hamilton Smith TEAL Classrooms, (2017). Technology Enabled Active Learning (TEAL) Classroom. www.unh.edu.

[14] Guthrie, H., Harris, R., Simons, M., \& Karmel, T. Teaching for technical and vocational education and training (TVET). International Handbook of Research on Teachers and Teaching, 21, 851-865 (2009).

[15] Hassan, N. F., \& Puteh, S. A Survey of Technology Enabled Active Learning in Teaching and Learning Practices to Enhance the Quality of Engineering Students. Advanced Science Letters, 23(2), 1104-1108 (2017).

[16] Sanusi, A. M., \& Puteh, S. An approach of excellence talent in engineering education programmed of enhancing the quality of students. Advanced Science Letters, 23(2), 1109-1112 (2017).

[17] Lee, Y., Boatman, E., Jowett, S., \& Guenther, B. REAL: The technology-enabled, engaged, and active learning classroom. International Journal of Designs for Learning, 5(1) (2014).

[18] Shieh, R.S., Chang, W., \& Tang, J. The impact of implementing technology enabled active learning (TEAL) in university physics in Taiwan. The Asia-Pacific Education Researcher, 19 (3). 401-415 (2010).

[19] Dori, Y.J., \& Belcher.W.J. How does Technology Enabled Active Learning affect undergraduate students' understanding of 
electromagnetism concepts?. The Journal of the Learning Sciences, 14 (2), 243-279(2005).

[20] Cinganotto, L., Panzavolta, S., Garista, P., Guasti, L., \& Dourmashkin, P. TEAL as an innovative teaching model. Insights from "educational avant-garde" movement in Italy. JeLKS Teaching Model. 12, 115-126 (2016).

[21] Van Hof, J. C. The effects of active learning technology on instructors 'practices and students 'engagement and grades: A Mixed Methods Study, (2016).

[22] Chiu, P. H. P. A Technology Enriched Active Learning Space for a New Gateway Education Programme in Hong Kong: A Platform for Nurturing Student Innovations. Journal of Learning Spaces, 5(1), 52-60 (2016).

[23] Ministry of education. Malaysia Education Blueprint 2015-2025 (Higher Education). ISBN 978-967-0334-99-8, 1-240 (2015).

[24] OECD. Education at a Glance 2016: OECD Indicators. OECD Publishing, Paris, (2016).

[25] Yee, R. Perceptions of online learning in an Australian university: an international students' (Asian region) perspective-quality of learning. International Journal of $e$ Education, e-Business, e-Management and e-Learning, 3(2) (2013).

[26] Colorado, J. T., \& Eberle, J. Student demographics and success in online learning environments. Emporia State Research Studies, 46(1), 4-10 (2010).

[27] Keengwe, J., \& Kidd, T. T. Towards best practices in online learning and teaching in higher education learning, 6(2), 533541 (2010).

[28] McBrien, J. L., Jones, P., \& Cheng, R. Virtual spaces: employing a synchronous online classroom to facilitate student engagement in online learning. International Review of Research in Open and Distance Learning, 10(3), 1-17 (2009).

[29] Wise, B. The online learning imperative: a solution to three looming crises in education. Education Digest: Essential Readings Condensed for Quick Review, 76(3), 52-58 (2010).

[30] Butler Kaler, C. A model of successful adaptation to online learning for college-bound Native American high school students. Multicultural Education \& Technology Journal, 6(2), 60-76 (2012).

[31] Means, B., Toyama, Y., Murphy, R., Bakia, M., \& Jones, K. Evaluation of evidence-based practices in online learning: $A$ meta-analysis and review of online learning studies. U.S. Department of Education, 94 (2009).

[32] Du, J., Liu, Y., \& Brown, R. L. The key elements of online learning communities. In Web-Based Education: Concepts, Methodologies, Tools and Applications, 119-132 (2010).

[33] Vaughan, N. D., Cleveland. I.M., \& Garrison, D. R. Teaching in Blended Learning Environments: Creating and Sustaining Communities of Inquiry. Athabasca, AB: Athabasca University Press, (2013).

[34] Norm, F. Report: Defining Blended Learning. Learning spaces papers, (2012).

[35] Bath, D. \& Bourke, J. Getting Started with Blended Learning. Griith University. Griith Institute for Higher Education, ISBN: 978-1-921760-24-2, (2010).

[36] Yen, J. C., \& Lee, C. Y. Exploring problem solving patterns and their impact on learning achievement in a blended learning environment. Computers and Education, 56(1), 138-145(2011).

[37] Edginton, A., \& Holbrook, J. A blended learning approach to teaching basic pharmacokinetics and the significance of face-toface interaction. American Journal of Pharmaceutical Education, 74(5), 88 (2010).

[38] Holley, D., \& Oliver, M. Student engagement and blended learning: Portraits of risk. Computers \& Education, 54(3), 693700 (2010).

[39] Azizan, F. Blended Learning in Higher Education Institution in Malaysia. In Proceedings of Regional Conference on Knowledge Integration in ICT, 454-466 (2010).

[40] Wu, J.H., Tennyson, R. D., \& Hsia, T.-L. A study of student satisfaction in a blended e-learning system environment. Computers \& Education, 55(1), 155-164 (2010).

[41] Fernandez Luna, J. M., Huete, J. F., Perez Vazquez, R., \& Rodriguez Cano, J. C. CIRLab: A groupware framework for collaborative information retrieval research. Information Processing and Management, 46(6), 749-761 (2010).

[42] Nam, N. H. Utilizing the active and collaborative learning model in the introductory physics course. Journal of Education and Learning, 3(3), 108-124 (2014).

[43] Verginadis, Y., Papageorgiou, N., Apostolou, D., \& Mentzas, G. A review of patterns in collaborative work. In Proceedings of the 16th ACM international conference on Supporting group work, 283 (2010).

[44] Bell, T., Urhahne, D., Schanze, S., \& Ploetzner, R. Collaborative inquiry learning: models, tools, and challenges. International Journal of Science Education, 32(3), 349-377 (2010).

[45] Kim, H.-N., Ji, A.-T., Ha, I., \& Jo, G.-S. Collaborative filtering based on collaborative tagging for enhancing the quality of recommendation. Electronic Commerce Research and Applications, 9(1), 73-83 (2010).

[46] Shukor, N. A., Tasir, Z., Van der Meijden, H., \& Harun, J. Exploring students' knowledge construction strategies in computer-supported collaborative learning discussions using sequential analysis. Educational Technology \& Society, 17(4), 216-228 (2014).

[47] Filigree. Instructional Technology and Collaborative Learning Best Practices: Global Report and Recommendations. Sponsor SMART Technologies (2012).

[48] Nguyen, N. H. Utilizing the Active and Collaborative Learning Model in the Introductory Physics Course. SSRN 2481765 (2014).

[49] Laal, M. Collaborative Learning; Elements. Procedia Social and Behavioral Sciences, 83, 814-818 (2013).

[50] Ahmad, C. N. C., Osman, K., \& Halim, L. Physical and psychosocial aspects of science laboratory learning environment. Procedia Social and Behavioral Sciences, 9, 8791(2010).

[51] Abdulwahed, M., \& Nagy, Z. K. Applying Kolb's experiential learning cycle for laboratory education. Journal of Engineering Education, 98, 283-294 (2009).

[52] Alam, F., Hadgraft, R. G., \& Subic, A. Technology enhanced laboratory experiments in learning and teaching. Using Technology Tools to Innovate Assessment, Reporting, and Teaching Prectices in Engineering Education, Hershey, United States, 289-302 (2014).

[53] Razali, Z. B., \& Daud, M. H. Approach of Assessing 'Handson'in Laboratory Exercises in Engineering Technology Courses. In Malaysia University Conference Engineering Technology (2014).

[54] Yao, J., Limberis, L., Warren, S., \& Asee. Enhancing Laboratory Experiences with Portable Electronics Experiment Kits, Asee Annual Conference (2012).

[55] Korchnoy, E., \& Verner, I. M. Characteristics of learning computer-controlled mechanisms by teachers and students in a common laboratory environment. International Journal of Technology and Design Education, 20(2), 217-237 (2010).

[56] Schuurbiers, D. What happens in the Lab: Applying Midstream Modulation to Enhance Critical Reflection in the Laboratory. Science and Engineering Ethics, 17(4), 769-788 (2011).

[57] Domagk, S., Schwartz, R. N., \& Plass, J. L. Interactivity in multimedia learning: An integrated model. Computers in Human Behavior, 26(5), 1024-1033(2010).

[58] Leow, F. T., \& Neo, M. Interactive multimedia learning: Innovating classroom education in a Malaysian university. Turkish Online Journal of Educational Technology, 13(2), 99110 (2014).

[59] Zulkifli, A. N., Noor, N. M., Bakar, J. A. A., Mat, R. C., \& Ahmad, M. A conceptual model of interactive persuasive learning system for elderly to encourage computer-based learning process. In Proceedings-International Conference on Informatics and Creative Multimedia, 7-12 (2013).

[60] Violante, M. G., \& Vezzetti, E. Virtual interactive E-learning application: An evaluation of the student satisfaction. Computer Applications in Engineering Education, 23(1), 72-91(2015). 
[61] Beauchamp, G., \& Kennewell, S. Interactivity in the classroom and its impact on learning. Computers \& Education, 54(3), 759766 (2010).

[62] Sabry, K., \& Barker, J. Dynamic Interactive Learning Systems. Innovations in Education and Teaching International, 46(2), 185-197 (2009). 